\title{
Influence of commercial copper microstructure on the artificial green patina formation processes ${ }^{(\bullet)}$
}

\begin{abstract}
R. Vera ${ }^{(*)}$, J. Pulgar ${ }^{(*)}$ y A. Olguín ${ }^{(*)}$
Abstract Commercial copper was submitted to a thermomechanical treatment in order to study its influence on the velocity of artificial green patina formation by immersion as well as on the thickness and adherence of the corrosion product formed on the underlying metal. The thermomechanical treatment enabled us to obtain samples with 9 to $60 \mu \mathrm{m}$ grain size. These samples were submitted to an accelerated attack by immersion in an electrolytic bath in order to obtain a green patina. On the smallest grain size material it can be observed a patina with high thickness and adherence, smooth texture and homogeneous morphology. From the electrochemical assays it was established that the passivity current decreases for decreasing grain sizes. These results are consistent with the minimal porosity presented by the patina morphology which increase the protecting power. The underlying material did not present localized attack.
\end{abstract}

Keywords: Copper. Patina. Grain size. Atmospheric corrosion.

\section{Influencia de la microestructura del cobre comercial sobre los procesos de formación de la pátina gris artificial}

\begin{abstract}
Resumen El cobre comercial se sometió a tratamiento termomecánico a fin de estudiar su influencia sobre la velocidad de formación artificial de pátina verde por inmersión, así como sobre el espesor y adherencia al sustrato metálico de los productos de corrosión formados. El tratamiento termomecánico permitía la obtención de muestras de 9 a $60 \mu \mathrm{m}$ de tamaño de grano. Estas muestras se sometieron a un ataque acelerado por inmersión en un baño electrolítico para obtener la pátina verde. Sobre el material de menor tamaño de grano se puede observar una pátina de elevado espesor y gran adherencia, textura fina y morfología homogénea. A partir de los ensayos electroquímicos se estableció que la corriente de pasivación disminuía para tamaños de grano decrecientes. Estos resultados son consecuentes con la pequeña porosidad presentada por la pátina, lo que incrementa su valor protector. El material subyacente no presentó ataque localizado.
\end{abstract}

Palabras clave: Cobre. Pátina. Tamaño de grano. Corrosión atmosférica.

\section{INTRODUCTION}

The formation of patinas on copper surface is a subject of great interest on these days, not only because of its aesthetic aspect but also, due to its protecting properties against the more diverse ambiental conditions. Patinas are constituted by chlorides, sulphates, oxides and hidroxides, which consolidates with exposure time, protecting the metal from further corrosion (1-3).

(•) Trabajo recibido el día 10 de marzo de 1997.

(*) Instituto de Química. Instituto de Física. Universidad Católica de Valparaíso. Fax: 056-32-273422. Casilla 4059. Valparaíso (Chile).
The yearly increasing pollution levels allow to forsee the need to control the process that before could be left to natural action. Conversely synthetic patinas can be formed throughout reactions in homogeneous environments of controlled agressivity to generate, by uniform and accelerated attack, a protective barrier for the metal exposed to a highly corrosive environments (4 y 5).

It has been studied the effect of a series of electrolytic solutions which accelerate the formation of patinas when they are applied on copper sheets by prolonged immersion times (6-9). These formed patinas present comparative advantage in time of generation, tonality and mechanical properties as compared to those formed 
using solutions already formulated. Adding different salts to a standard solution it has been obtained patinas of different colors: brown, green, light blue and violet, all of them having excellent resistance and aesthetics properties. The patinas formed on copper sheets are mainly composed by $\mathrm{Cu}_{2} \mathrm{O}$ and $\mathrm{Cu}_{4} \mathrm{SO}_{4}(\mathrm{OH})_{6}$ and their formation was accelerated by aereation and temperature increase.

Franey and col. (10) performed metalographic studies in 14 natural patinas exposed to atmospheric conditions for periods between 1 and 100 years. Micrographies in cross sections indicated that the patina structures showed voids through which their development continue. Heat treatment, grain size, and material composition have a strong effect on patina structure and formation. There is a direct correlation between grain size, surface defect density and thickness of the patina.

Even if the general aspects of patina formation by immersion seems to be clear, there are still some questions to be solved. One of these aspects, and the aim of these work, is to determine the influence that the grain size of the base material has on the definition of the final patina color, rate of formation, thickness and adhesion to the underlying metal.

\section{MATERIALS AND METHODS}

The present study has been carried out with samples of commercial copper of $97.0 \%$ purity (M0). The samples (M1, M2 and M3) were cut and annealed during $9 \mathrm{~h}$ at $800{ }^{\circ} \mathrm{C}$; sample M1 was deformed in a 41,3\% by compression and subsecuently annealed in a salt bath at $800{ }^{\circ} \mathrm{C}$ during $1 \mathrm{~h}$ and only M2 was quenched. The sample M4 was annealed during $48 \mathrm{~h}$ at $800{ }^{\circ} \mathrm{C}$. Then, all the specimens were prepared for metallographic and microscopic analysis; small samples were grounded with $\mathrm{SiC}$ papers of grades 400,500 and 600 , and subsecuently polished with alumina paste of $1 \mu \mathrm{m}$ and $0.05 \mu \mathrm{m}$, degreased and dried in a hot air stream. The metallographic observations were carried out in an optical microscope employing a sample polished in a electrolytic solution containing $\mathrm{H}_{3} \mathrm{PO}_{4}$, ethanol, urea and propanol and its microstructure was developed in $\mathrm{HNO}_{3}$ 1:1 solution. The grain size was measured using the mean linear intercept method. After these, the copper samples were immersed by 3 days in an electrolytic bath (9) with controlled temperature and continuous aeration to obtain the patina on the surface.

The chemical composition of patinas was determined through X-ray diffraction in a Philips PW 3710 diffractometer with copper anode, obtaining very definite diagrams due to the high crystalinity of their constituent products. Patinas morphology were determined through SEM, with a
Leitz-AMR 1000 microscope. Plant and cross sections samples were observed, the latest after polishing up to alumina paste of $0.3 \mu \mathrm{m}$.

Polarization curves were obtained in $\mathrm{Na}_{2} \mathrm{SO}_{4} 0.1$ $\mathrm{M}$, at room temperature, in the presence of air, at a scan rate of $1 \mathrm{mVs}^{-1}$ in a conventional Pyrex glass cell, with Pt counter electrode and saturated calomel reference electrode. A Tacussel potentiostat PRT 30, with LA-141 scanner generator and X-y register was used.

\section{RESULTS AND DISCUSSION}

Table I summarizes the results concerning to the grain size obtained for each sample thermomechanically treated and employed in the corrosion experiments.

Figure 1 shows the optical micrographs of the original material. As it can be observed from this micrographs, the microstructure of the alloy is constituted by elongated and equiaxed grains, in general, a non homogeneous structure.

Figure 2 shows the microstructure corresponding to the specimens (M1, M2, M3 and M4) with different grain size. M1 (Fig. 2a) shows an homogeneous microstructure and the smallest grain size obtained. It is known that when the degree of porcentual strain applied increases, the recristallized grain size decreases. Then, the microstructure showed by M1 may be due to the recristallization process carried out by the activation of a large number of nuclei induced by a high internal stored energy associated to a high degree of deformation.

Figures $2 b, 2 c$ and $2 d$ show an homogeneous microstructure and a larger grain size. The differences observed between M2, M3 and M4 are due to the different procedures they had been submitted after thermic treatment; M2 was quenched, M3 and M4 were cooled in a furnace.

The specimens were used to develop on them artificial patinas by immersion in an electrolytic bath. X-ray diffraction and IR spectroscopy diagram of patina indicated that the composition of the patina in all the specimens was mainly brochantite and cuprous oxide as secondary component, showed in figure 3 . The green color was similar in all the samples. This results confirm that the color and composition of the patina are

TABLE I.- Grain size of the specimens TABLA I.- Tamaño de grano de las probetas

\begin{tabular}{|c|c|c|c|c|}
\hline Sample & M1 & M2 & M3 & M4 \\
\hline$d, \mu \mathrm{m}$ & $9 \pm 1$ & $18 \pm 2$ & $34 \pm 3$ & $60 \pm 6$ \\
\hline
\end{tabular}

Rev. Metal. Madrid, 33 (6), 1997 


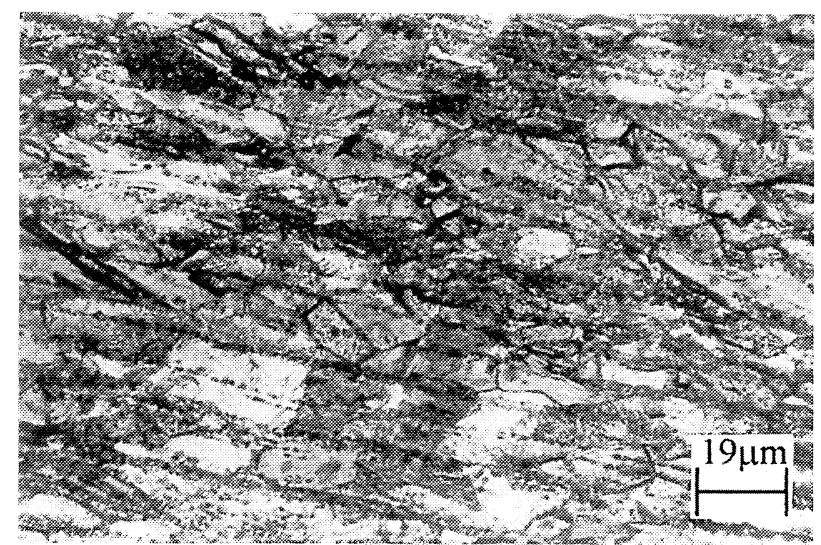

FIG. 1.- Micrograph of the original material, M0.

\section{FIG. 1.-Micrografía del material original, MO.}

independent of the grain size of the underlying material and only depend on the composition of the electrolytic bath.

Figure 4 shows in plant micrographs of different surface morphologies corresponding to smooth and rough textures of the corrosion products. Observations $100 \times$ of this samples point out that the aspect of the corrosion products formed on specimen of small grain size (M1) were more homogeneus and smooth, which indicated a contrast between the uniformity of the patinas obtained on the samples of different grain size.

Furthermore, from plant micrographies $1,000 \times$ (Fig. 5) it is possible to appreciate that in sample M1 the morphology of the patina is more compact. This morphology gives to the patina more protective characteristics against polluted environments.

M1 and M3 were submitted to an identical artificial patina formation process. The respective micrographs of the cross section are shown in figure 6 . The corrosion product texture observed in both samples was uniform but the thickness of the formed product is slightly thinner in M3 than in M1, this was measured using an adecuate measuring software; for M1 was $8 \mu \mathrm{m}$ and M3 was $7 \mu \mathrm{m}$. These facts can be explained the corrosion rate is higher when it is produced on a surface which is more homogeneous and has a smaller grain size.

Figure 7 shows the average anodic polarization curves obtained with patinas formed on copper of different microstructure.

From polarization results a greater protectiveness can be appreciate in the M1 sample, due to its low passivity current, $i_{\mathrm{p}}$, and great passivity range. The plant view of figure $4 \mathrm{a}$ allows to relate them with structures of minimum porosity. For M2, M3 and M4 samples a passivity range similar to that in M1 was found, but the respective
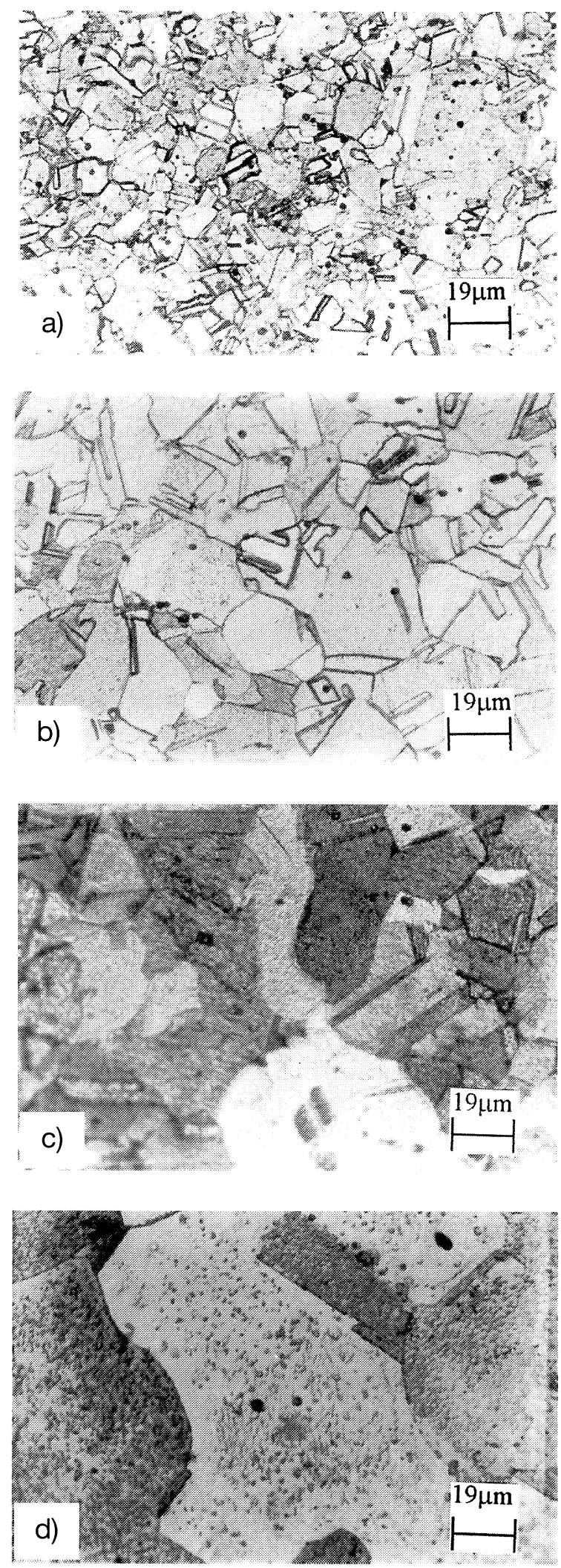

FIG. 2.- Micrographs of samples of different grain sizes: a) M1, $9 \mu \mathrm{m}$; b) M2, $18 \mu \mathrm{m}$; c) M3, $34 \mu \mathrm{m}$ and d) M4, $60 \mu \mathrm{m}$.

FIG. 2.- Micrografías de probetas con diferentes tamaños: a) M1, $9 \mu \mathrm{m}$; b) M2, $18 \mu \mathrm{m}$; c) M3, 34 нm y d) $M 4,60 \mu m$. 

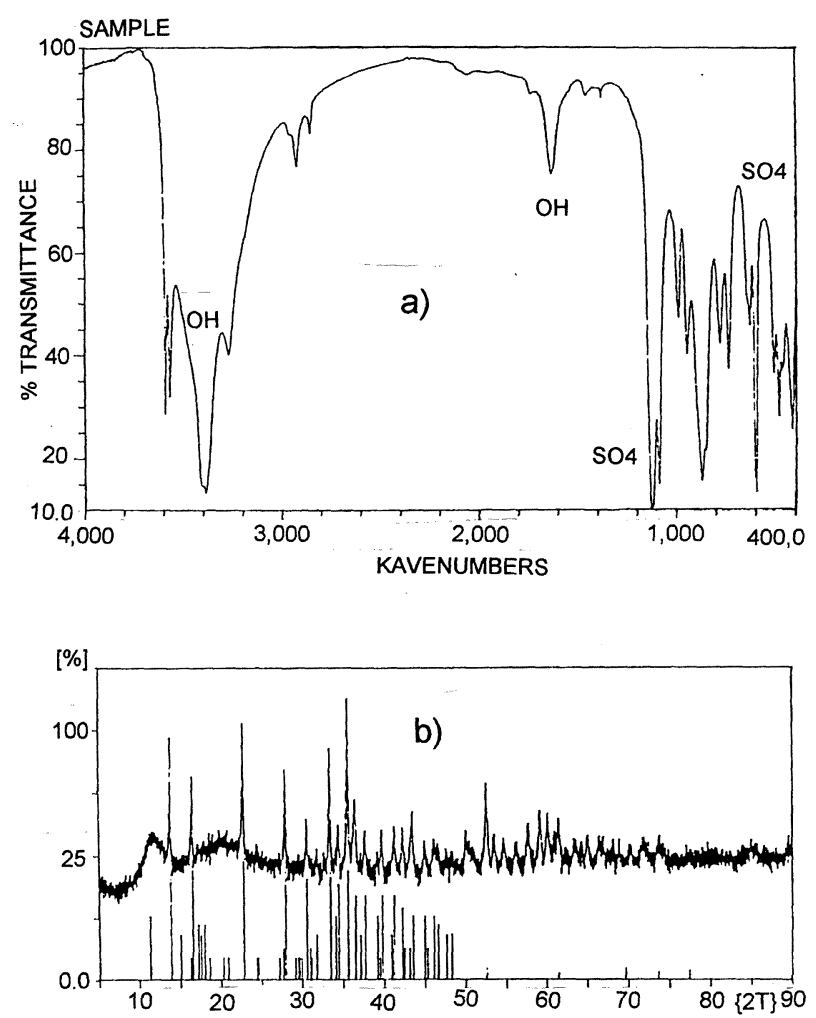

FIG. 3.- a) X-ray diffraction of patina and b) IR spectroscopy diagram of patina.

FIG. 3.- a) Difracción de rayos $X$ de una pátina, $y$ b) Diagrama de espectroscopía de IR de una pátina.

$i_{\mathrm{p}}$ is magnitud greater, which is consistent with open morphology of products in figure 4 (b, c and d). On the other hand, the dissolution current is greater when the patina is formed on a copper surface with larger grain size, having a less protecting power.

Table II summarizes the results obtained from the polarization curves and from the plant micrographs of the different samples analized. The size $(t)$, the number $(n)$ of flakes and the frecuency $(n / A)$ were obtained from the micrographs using an adecuate software, and the passive current data were extrapolated from figure 7 .

From these results it can be observed that: patinas formed on a surface with smaller grain size (M1) show a larger number of flakes and the frecuency expressed as $n / A$ too is largest. Furthermore, the passive current observed has the lowest value in sample M1. These data indicated that the morphology of the corrosion product is more compact and less porous when it is formed on a surface with small grain size, which imply a higher protector power.

The potentiostatic polarization measurement for copper specimens of different microstructure with patinas in $0.1 \mathrm{M} \mathrm{Na}_{2} \mathrm{SO}_{4}$ solution showed a
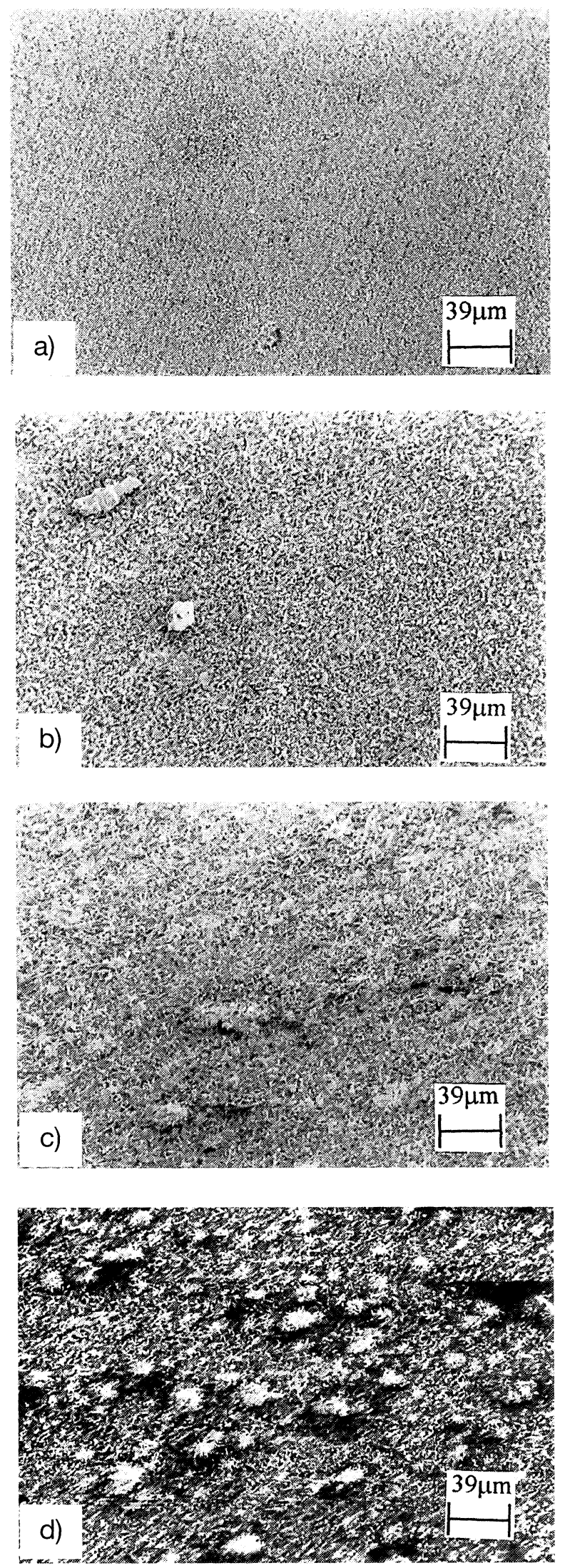

FIG. 4.- In plant micrographs of patina samples, 100×: a) M1; b) M2; c) M3 and d) M4.

FIG. 4.- Micrografías en planta de probetas de pátina, x100: a) MI; b) M2; c) M3 y d) M4. 

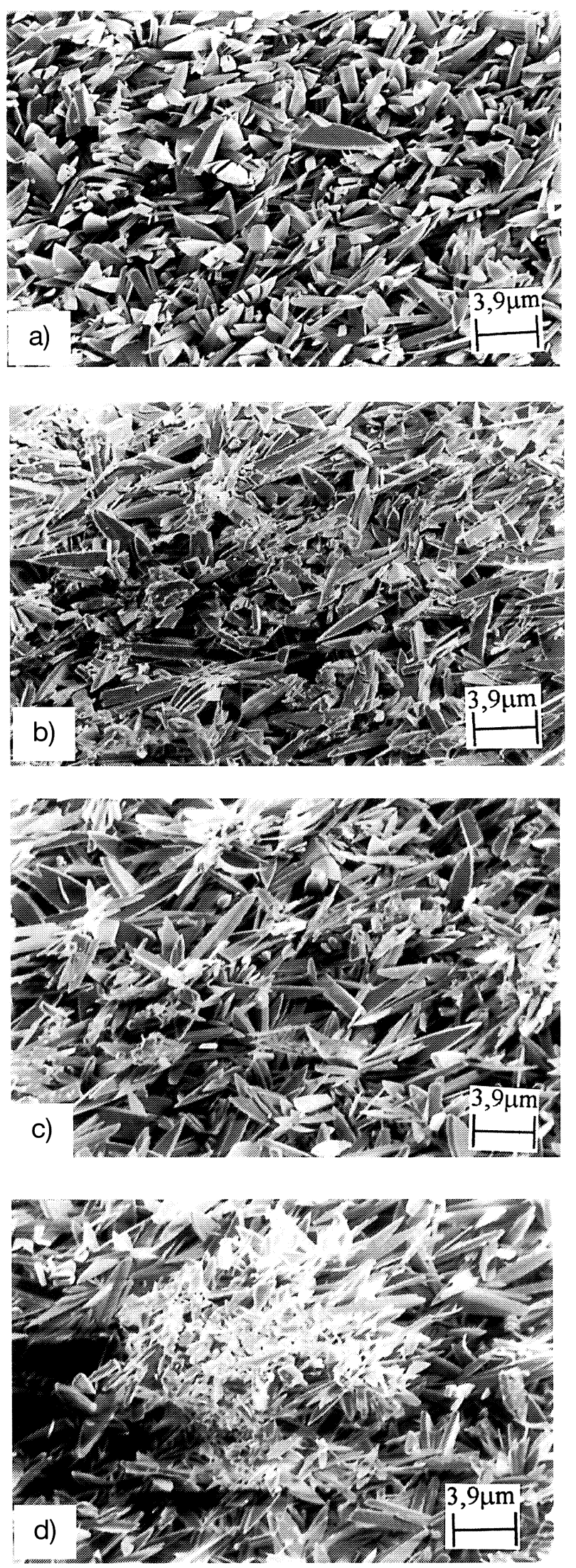

FIG. 5.- In plant micrographies of patina samples, 1,000×: a) M1; b) M2; c) M3 and d) M4.

FIG. 5.- Micrografías en planta de probetas de pátina, X1.000: a) M1; b) M2; c) M3 y d) M4.
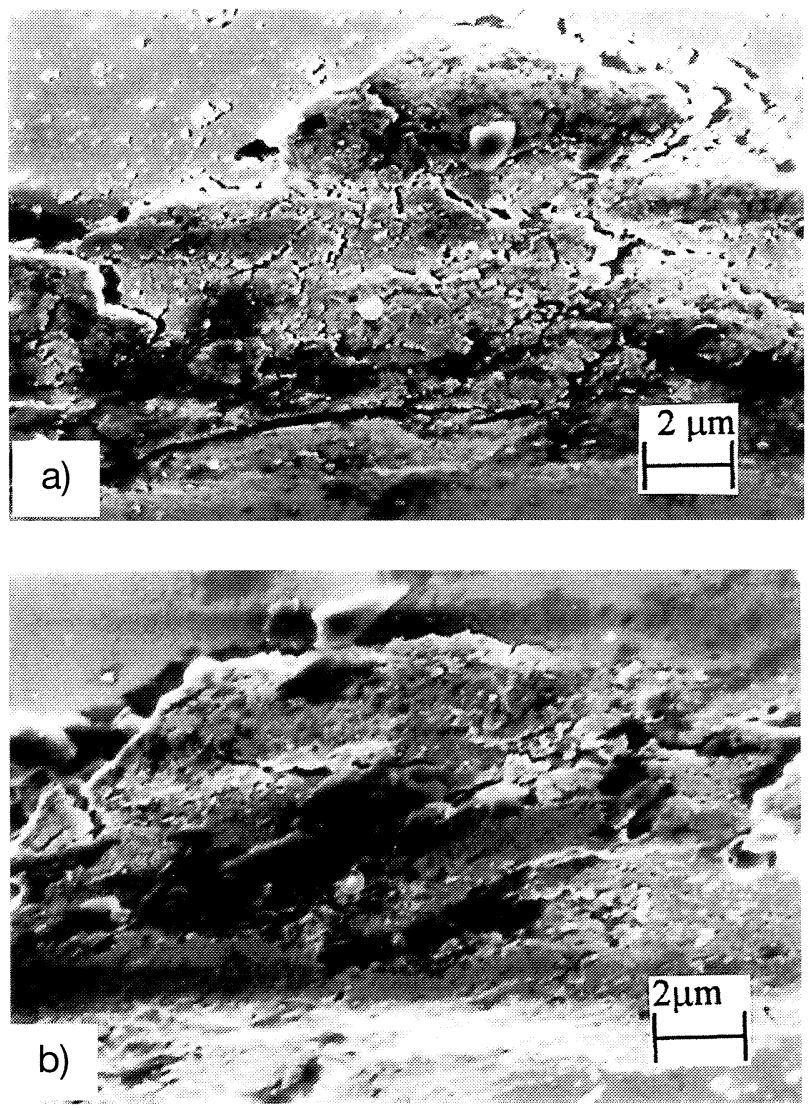

FIG. 6.- Micrograph of the cross section of patina samples, 2,000×: a) M1 and b) M3.

FIG. 6.- Micrografía de la sección transversal de probeta de pátina, X2.000: a) M1 y b) M3.

considerable difference in the stable current density as shown in figure 8 . The presence of the patina formed on a surface with small grain size resulted

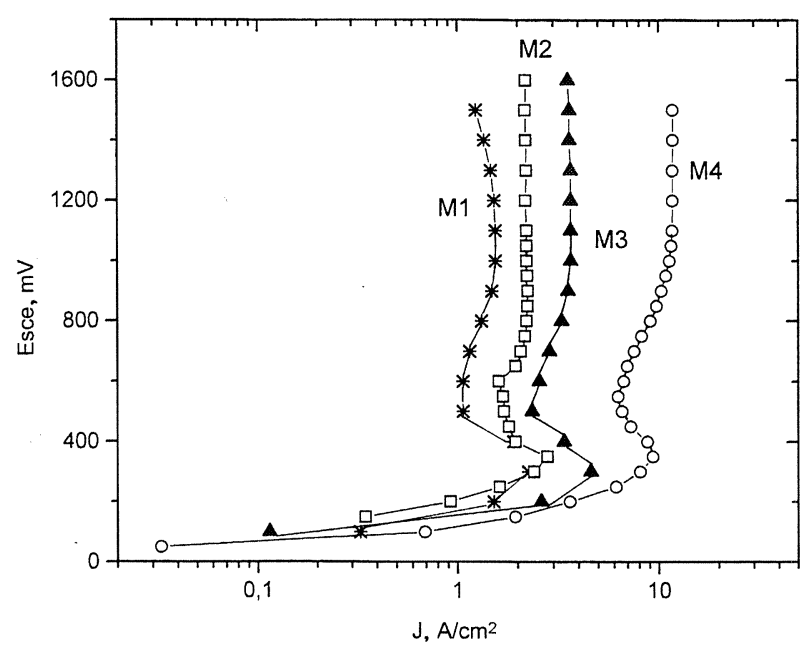

FIG. 7.- Anodic polarization curves of patina samples in $\mathrm{Na}_{2} \mathrm{SO}_{4}, 0.1 \mathrm{M}$.

FIG. 7.-Curvas de polarización anódica de probetas de pátina en $\mathrm{Na}_{2} \mathrm{SO}_{4}, 0,1 \mathrm{M}$. 
TABLE II.- Patina characteristics TABLA I.-Características de las pátinas

\begin{tabular}{|c|c|c|c|c|c|}
\hline Sample & $\begin{array}{c}d, \\
\mu \mathrm{m}\end{array}$ & $\begin{array}{c}t, \\
\mu \mathrm{m}\end{array}$ & $n$ & $\begin{array}{c}n / A, \\
1 / \mu \mathrm{m}^{2}\end{array}$ & $\begin{array}{c}i_{\mathrm{p}}, \\
\mathrm{mA} \mathrm{cm}^{-2}\end{array}$ \\
\hline M1 & 9 & 2,1 & 574 & 0.72 & 1,5 \\
M2 & 18 & 2,4 & 402 & 0.50 & 2,0 \\
M3 & 34 & 2,6 & 344 & 0.43 & 3,0 \\
M4 & 60 & 3,0 & 268 & 0.34 & 9,0 \\
\hline
\end{tabular}

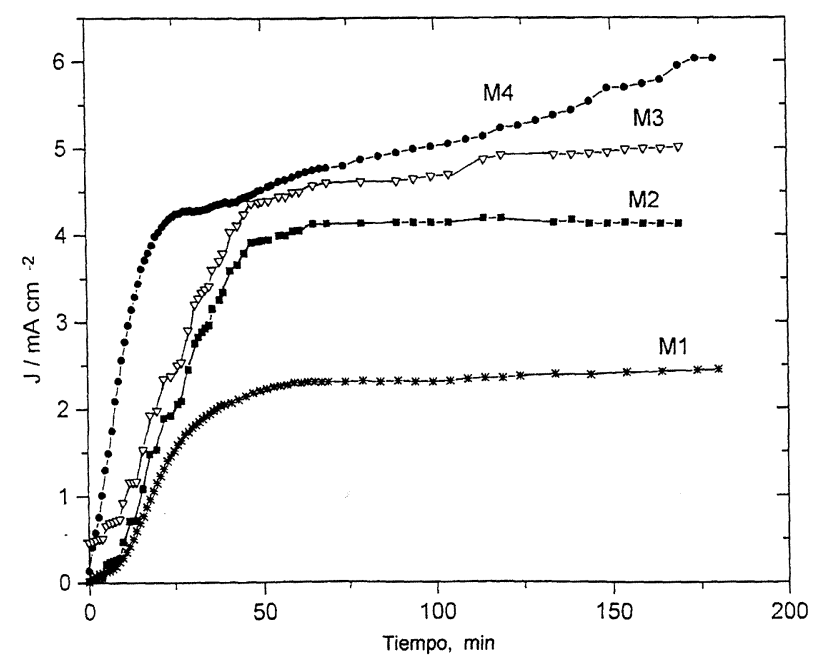

FIG. 8.- Potenciostatic polarization curves of patina samples in $\mathrm{Na}_{2} \mathrm{SO}_{4}, 0.1 \mathrm{M}$, Esce $=100 \mathrm{mV}$.

FIG. 8. - Curvas de polarización potenciostática de probetas de pátina en $\mathrm{Na}_{2} \mathrm{SO}_{4}, 0,1 \mathrm{M}$, Esce = $100 \mathrm{mV}$.

in much lower stable state current density during polarization than for the metal with a larger grain size. Furthermore, it is observed that M4 sample reached higher current density in less time than the others. These results supported examination by scanning electron microscopy where the aspect of the patinas formed on specimens of small grain size were more homogeneous, more compact and smoother.

A protective patina is an efficient barrier which isolates the underlying metal from agressive environments, the best patinas turned out to be those formed on copper with a small grain size microstructure. Their protective properties could be higher than those formed during copper atmospheric corrosion in very polluted environments.

\section{CONCLUSIONS}

The properties of the corrosion products formed on copper samples of small grain size show small and well packed structures morphology, low current and wide passivity range, smooth texture and absence of localized attack. Therefore a small grain size microstructure is better for artificial patinas formation on copper, because it provides a most efficient barrier which isolates from agressive environment the underlying metal.

Finally, it can say that thermomechanical treatment to reduce grain size is a good alternative process to obtain patinas with high protective power on copper.

\section{Acknowledgments}

The authors are deeply grateful for the financial support by Dirección General de Investigación, Proyecto 125.740, Universidad Católica de Valparaíso, Chile. We also thank Dra. Blanca M. Rosales, from CEICOR; Argentina, for her helpful discussion of this paper.

\section{REFERENCES}

(1) Oguchi, H., Ichinashi, T. and Nuyama, S. Informe $\mathrm{N}^{\circ} 1$, 10.3 Chome, Tsukiji, Chuo-Ku, Tokio (Japón).

(2) Graedel, T., Nassau, K. and Franey, J. Corros. Sc., 27 (7), 1987: 639-657.

(3) Nassau, K., Miller, A., Graedel, T. and Gallagher, P. Corros. Sci., 27 (7), 1987: 680-681.

(4) Nassau, K., Miller, A. and Graedel, T. Corros. Sci., 27 (7), 1987: 703-719.

(5) Graedel, T. Corros. Sci., 27 (7), 1987: 721-740.

(6) Vera, R., Layana, G., Olguin, A. y Rosales, B. Proc. 3er Congreso de la Asociación Latinoamericana de Metalurgia y Materiales, Antofagasta (Chile), Agosto 1994.

(7) Vera, R., Layana, G. y Gardiazabal, J.Y. Proc. $2^{\circ}$ Congreso Latinoamericano en Metalurgia e Ingeniería de Materiales. Estado de México (México), 1992.

(8) Vera, R., Layana, G. y Gardiazabal, J.I. Proc. XX Jornadas Chilenas de Química. Punta de Tralca (Chile), 1993.

(9) Vera, R., Layana, G. y Gardiazabal, J.I., Bol. Soc. Chil. Quím., 40, 1995: 149-156.

(10) Franey, J.P. and Davis, M.E., Corros. Sci., 27 (7), 1987: 659-668. 